This item was submitted to Loughborough's Research Repository by the author.

Items in Figshare are protected by copyright, with all rights reserved, unless otherwise indicated.

\title{
Determination of iodine and molybdenum in milk by quadrupole ICP-MS
}

PLEASE CITE THE PUBLISHED VERSION

PUBLISHER

(C) Elsevier

LICENCE

CC BY-NC-ND 4.0

\section{REPOSITORY RECORD}

Reid, Helen J., Abdulaziz S. Bashammakh, Phillip S. Goodall, Mark R. Landon, Ciaran O'Connor, and Barry L. Sharp. 2019. "Determination of lodine and Molybdenum in Milk by Quadrupole ICP-MS". figshare. https://hdl.handle.net/2134/3268. 
This item was submitted to Loughborough's Institutional Repository by the author and is made available under the following Creative Commons Licence conditions.

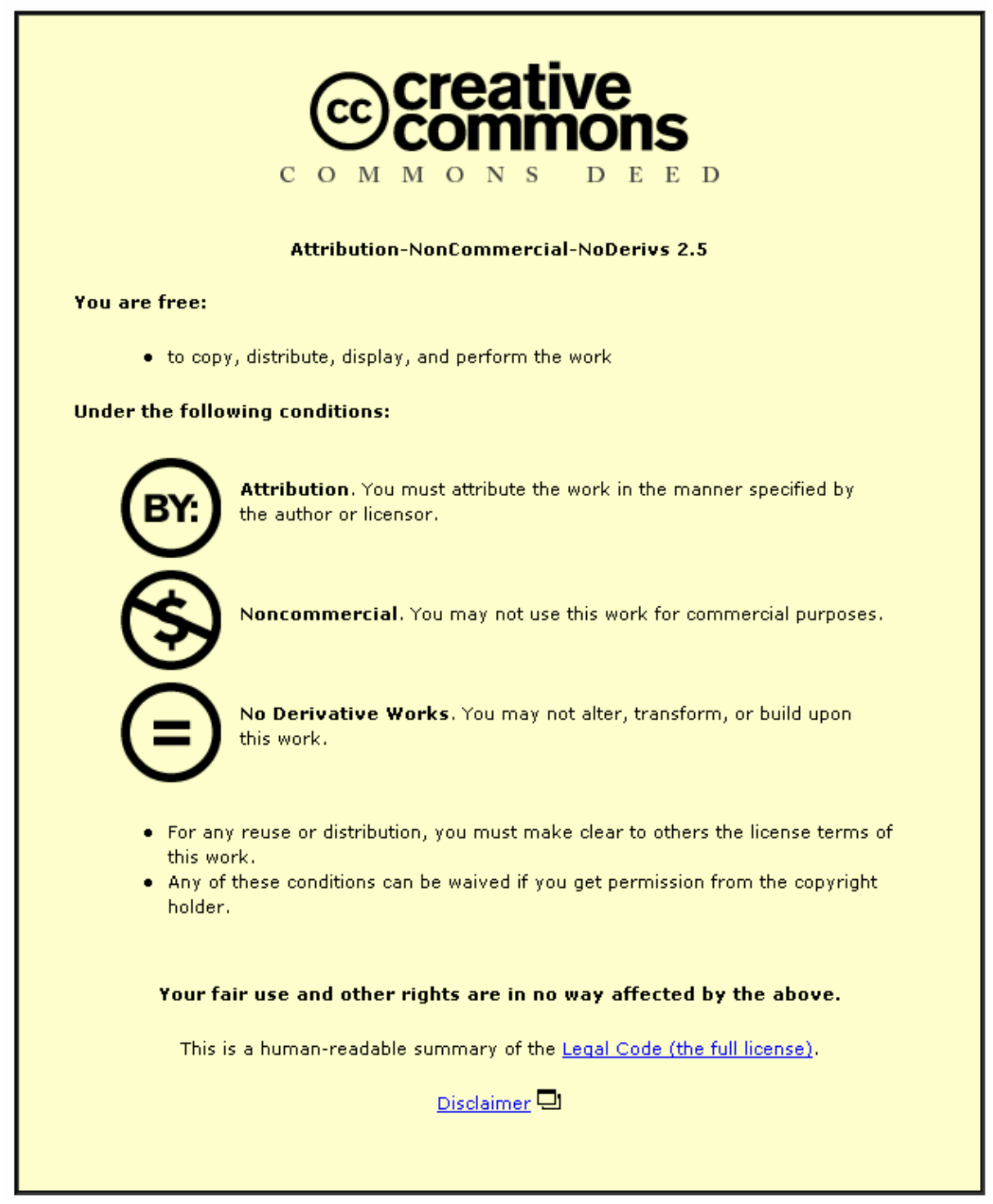

For the full text of this licence, please go to: http://creativecommons.org/licenses/by-nc-nd/2.5/ 
NOTICE: this is the author's version of a work that was accepted for publication in Talanta. Changes resulting from the publishing process, such as peer review, editing, corrections, structural formatting, and other quality control mechanisms may not be reflected in this document. Changes may have been made to this work since it was submitted for publication. A definitive version was subsequently published in Talanta, Volume 75, Issue 1, 15 March 2008, Pages 189-197 (doi:10.1016/i.talanta.2007.10.051)." 


\title{
Determination of iodine and molybdenum in milk by quadrupole ICP-MS
}

Helen J. Reid ${ }^{\star a}$, Abdul A. Bashammakh ${ }^{b}$, Phillip S Goodall ${ }^{c}$, Mark R. Landon ${ }^{\mathrm{a}}$, Ciaran O'Connor ${ }^{a}$, and Barry L. Sharp ${ }^{a}$

aDDepartment of Chemistry, Loughborough University, Loughborough, Leics, LE11 3TU, UK. bepartment of Chemistry, Faculty of Science, King Abdulaziz University, P. O. Box 80203, Jeddah 21589, Kingdom of Saudi Arabia.

${ }^{\mathrm{c}}$ Nexia Solutions, Sellafield, Seascale, Cumbria, CA20 1PG, UK.

\begin{abstract}
A reliable method for the determination of iodine and molybdenum in milk samples, using alkaline digestion with tetramethylammonium hydroxide and hydrogen peroxide, followed by quadrupole ICP-MS analysis, has been developed and tested using certified reference materials. The use of $\mathrm{He}+\mathrm{O}_{2}\left(1.0 \mathrm{ml} \mathrm{min}^{-1}\right.$ and $\left.0.6 \mathrm{ml} \mathrm{min}{ }^{-1}\right)$ in the collision-reaction cell of the mass spectrometer to remove ${ }^{129} \mathrm{Xe}^{+}$- initially to enable the determination of low levels of ${ }^{129} \mathrm{I}$ - also resulted in the quantitative conversion of $\mathrm{Mo}^{+}$to $\mathrm{MoO}_{2}{ }^{+}$which enabled the molybdenum in the milk to be determined at similar mass to the iodine with the use of $\mathrm{Sb}$ as a common internal standard. In order to separate and pre-concentrate iodine at sub $\mu \mathrm{g} \mathrm{L}^{-1}$ concentrations, a novel method was developed using a cation-exchange column loaded with $\mathrm{Pd}^{2+}$ and $\mathrm{Ca}^{2+}$ ions to selectively retain iodide followed by elution with a small volume of ammonium thiosulfate. This method showed excellent results for aqueous iodide solutions, although the complex milk digest matrix made the method unsuitable for such samples. An investigation of the iodine species formed during oxidation and extraction of milk sample digests was carried out with a view to controlling the iodine chemistry.
\end{abstract}


Keywords: lodine, collision-reaction cell, molybdenum, milk, sample preparation, ICP-MS Introduction

Milk is recognized as the most complete food in the human diet because it contains all the macronutrients such as proteins, lipids and carbohydrates and all the essential micronutrients such as elements, vitamins and enzymes. A lot of information has been accumulated concerning the composition of milk in terms of fat, protein and vitamins [1]; however, less attention has been paid to the elemental composition of milk in spite of the great importance of essential elements in nutrition [2,3].

lodine is one of the most important trace elements in human nutrition; its physiological function as a constituent of thyroxine, the hormone secreted by the thyroid gland, necessitates the control of intake levels, as deficiency or excessive exposure both have a detrimental affect on thyroid function [1,4]. Concentrations of iodine in cow's milk, which is a major contributor to dietary exposure, are naturally influenced by the levels of iodine in feedstuffs, which vary seasonally [5]. It has been reported that iodine in milk is present mostly as free iodide [6] with relatively small amounts of organic iodine. Whilst ${ }^{127} \mathrm{I}$ is the only stable isotope, the most hazardous iodine species are the radioactive isotopes such as ${ }^{129}$ I and ${ }^{131}$ I which may enter the food chain via the air-grass-cow-milk pathway as a result of aerial emissions from nuclear reprocessing plants [7]. The long-lived radionuclide ${ }^{129} \mathrm{I}$ is monitored by regular measurement of ${ }^{129}$ I content of liquid milk from cows in the potentiallyaffected areas $[8,9]$, typically by radiometric analysis after appropriate separation techniques [10].

Inductively-coupled plasma mass spectrometry (ICP-MS) potentially offers a quick, simple method of monitoring iodine isotopes in milk; however there are a number of problems associated with the use of ICP-MS for this assay. Firstly, iodine has a relatively high detection limit in ICP-MS in comparison to other elements due to its high ionisation potential (10.45 eV). Also, signal memory effects can be a problem, due to evaporation of iodine as $\mathrm{HI}$ 
or $\mathrm{I}_{2}$ from aerosol droplets in the spray chamber [11]. Furthermore, interference on the ${ }^{129} \mathrm{I}^{+}$ signal arises from ${ }^{129} \mathrm{Xe}^{+}$and possibly also ${ }^{127} \mathrm{IH}_{2}{ }^{+}$ions [12,13], making the use of oxygen as a collision/reaction gas an attractive option for this analysis.

Before considering instrumental conditions, however, it is necessary to carefully consider sample preparation, to avoid losses due to iodine's volatility and complex redox chemistry. At low $\mathrm{pH}$ iodide is easily oxidised to volatile molecular iodine by dissolved oxygen (or other dissolved oxidants):

$$
4 \mathrm{I}^{-}+\mathrm{O}_{2(\mathrm{~g})}+4 \mathrm{H}^{+} \rightarrow 2 \mathrm{H}_{2} \mathrm{O}+2 \mathrm{I}_{2(\mathrm{aq})} \quad \mathrm{E}^{0}=0.61 \mathrm{~V}
$$

At high $\mathrm{pH}$, the oxidation of iodide to iodine is avoided, and it is therefore usual to prepare samples in alkaline media to prevent the oxidation of $\mathrm{I}^{-}$to $\mathrm{I}_{2}$ or the formation of $\mathrm{HI}$. With milk samples, it is also important to destroy the organic matrix to reduce the spectral interferences from carbon species and the possibility of cone blockage in the ICP-MS interface. Thus decomposition with strong alkali, such as ammonia, potassium hydroxide or tetramethylammonium hydroxide (TMAH), alone or in combination, has been used to prepare milk samples for iodine determination $[4,11,14,15]$. These procedures lead to the conservation of the iodine as iodide or iodate, which is then determined by ICP-MS regardless of the iodine species present in the original sample. The use of alkaline conditions also potentially enable the simultaneous determination of other important anion-forming elements such as selenium, arsenic, sulfur and molybdenum, though this aspect appears to have received little attention in the literature, iodine usually being determined separately from other trace elements. The flexibility of this sample preparation technique is illustrated in the present study by the successful determination of molybdenum, an essential nutrient required for the function of molybdoenzymes, such as milk xanthine oxidase which catalyses the oxidation of xanthine to uric acid [16]. 
For iodine determination alone, an alternative approach is to deliberately convert iodine in the sample to elemental iodine vapour for analysis, and total iodine has been determined in milk by vapour generation ICP-optical emission spectrometry [17], though an alkaline digestion was still required to destroy the organic matrix prior to generating the iodine vapour. lodine has been determined directly in milk powder by electrothermal vaporizationICP, but again interference from the organic matrix was a problem, necessitating the use of pre-reduced Pd as a chemical modifier and internal standard [18].

The work reported here describes the preparation of milk samples for the determination of iodine and molybdenum by ICP-MS using sample pre-concentration and hexapole collisionreaction cell technology. The first aim was to develop a straightforward digestion method to break down the organic matrix of the milk, without loss of analyte, yielding a clear solution suitable for continuous nebulisation and analysis by ICP-MS. Once this was achieved, attention turned to preconcentration of the digest before introduction to the ICP-MS to improve detection limits. To determine ${ }^{129} \mathrm{I}$, the use of oxygen in the hexapole collisionreaction cell of the instrument removes ${ }^{129} \mathrm{Xe}^{+}$ions by a rapid charge-transfer mechanism (equation (2)) [19], thus preventing them interfering with ${ }^{129}$ I determination.

$$
\mathrm{Xe}^{+}+\mathrm{O}_{2} \rightarrow \mathrm{Xe}+\mathrm{O}_{2}^{+} \quad \Delta \mathrm{H}=-0.06 \mathrm{eV} ; \mathrm{k}=1.10 \times 10^{-10} \mathrm{~cm}^{3} \mathrm{~s}^{-1}
$$

It has been reported that ${ }^{129} \mathrm{Xe}^{+}$reacts $10^{4}$ times faster with $\mathrm{O}_{2}$ than ${ }^{129} \mathrm{I}^{+}$does [20] and thus use of oxygen can selectively remove ${ }^{129} \mathrm{Xe}^{+}$. This may also be of importance in facilitating the use of low level ${ }^{129}$ I spikes for isotope dilution determination of ${ }^{127}$ | [21]. 


\section{Experimental}

\section{Instrumentation}

A VG PQ ExCell with Collision Cell Technology (CCT) (Thermo Elemental, Winsford, Cheshire, UK), was employed for ICP-MS analysis. The instrument, located in a generalpurpose laboratory without air filtration or conditioning equipment, was used with a polyamide or glass nebuliser, a silica impact bead spray chamber, cooled to $5^{\circ} \mathrm{C}$ by a Peltier cooler, and standard silica torch. Standard nickel sample and skimmer cones were used.

The ion optics were tuned to optimise the sensitivity of the signal at $\mathrm{m} / \mathrm{z} 115$ for a $1 \mu \mathrm{g} \mathrm{L}^{-1}$ indium solution, which was typically $60,000-120,000$ counts $\mathrm{s}^{-1}$ in standard (non-CCT) mode. The relative standard deviation of $1 \mu \mathrm{g} \mathrm{L}^{-1}{ }^{115}$ In signals was less than $1.5 \%$ and the oxide levels were monitored to ensure the ${ }^{140} \mathrm{Ce}+/{ }^{140} \mathrm{Ce}^{16} \mathrm{O}^{+}$ratio did not exceed 0.02 . Typical operational conditions for the ICP-MS are given in Table 1.

$\mathrm{Sb}\left(200 \mathrm{ng} \mathrm{g}^{-1}\right)$ was used as the internal standard and dilute tetramethylammonium hydroxide (TMAH, $0.5 \%$ in water) was used as the wash solution, with a 4 min washout time between samples (extended from the normal $90 \mathrm{~s}$ to prevent carryover of iodine).

For removal of ${ }^{129} \mathrm{Xe}$, helium and oxygen were introduced into the collision cell while aspirating a $5 \mathrm{ng} \mathrm{g}^{-1}$ iodide solution. With the He flow rate set to $1 \mathrm{~mL} \mathrm{~min}^{-1}$, the $\mathrm{O}_{2}$ flow was varied to maximise the $127 / 129$ signal ratio whilst retaining sufficient sensitivity for iodine determination. Similarly pole bias settings of both the hexapole and quadrupole analyzer were adjusted to produce a high $127 / 129$ ratio. Optimal conditions established this way were $\mathrm{O}_{2}$ flow $0.6 \mathrm{ml} \mathrm{min}-1$ with a hexapole bias of $-2 \mathrm{~V}$ and quadrupole bias of $-10 \mathrm{~V}$. The slight negative bias on the hexapole is expected because the charge transfer reaction of Xe with $\mathrm{O}_{2}$ is slightly endothermic $(+0.06 \mathrm{eV})$ and is therefore favoured by more energetic ions [22]. 
Table 1. Typical operating parameters for the VG PQ ExCell

\begin{tabular}{lll}
\hline $\begin{array}{l}\text { RF Power / W } \\
\text { Gases / / } \text { min }^{-1}\end{array}$ & 1350 \\
& Plasma & 12.60 \\
& Auxiliary & 0.80 \\
& Nebuliser & 1.03 \\
& Tuned for optimum In signal \\
Lenses & -1.96 \\
Hexapole pole bias / V & -119.4 \\
L3 / V & +20.9 \\
Focus / V & -35.8 \\
Deflector lens / V & +1 or $-10^{\mathrm{a}}$ \\
Quadrupole pole bias / V & Tuned for optimum In signal \\
Torch position &
\end{tabular}

\section{Acquisition Parameters}

No of scans 100

Channels per mass $\quad 1$

Dwell time / ms 10

No of replicates 5

Scanning mode Peak jump

$\mathrm{m} / \mathrm{z}$ measured $\quad 92,95,96,97,98,121,123,124,127,128,129,130,131$ 132

Delay time/s 90

Wash time/s 90

${ }^{a}$ denotes quadrupole bias when collision cell mode enabled

Unicam 8700 series and Shimadzu UV-1601PC UV-Visible spectrophotometers were employed to monitor the presence of $\mathrm{I}_{2}, \mathrm{I}^{-}$and $\mathrm{I}_{3}{ }^{-}$in oxidation experiments.

A 757 VA Computrace (Metrohm, Herisau, Switzerland) was used for the electrochemical oxidation of potassium iodide in $0.1 \mathrm{M} \mathrm{KCl}$ using a platinum electrode with a potential sweep of $-1.2 \mathrm{~V}$ to $1.2 \mathrm{~V}$. 


\section{Materials and Reagents}

Certified reference materials (CRMs) produced by the National Institute of Standards and Technology (Dried Whole Milk, NIST 8435) and the European Community Bureau of Reference (Dried Skimmed Milk, BCR 063R) were purchased from LGC, Teddington. A further sample of the NIST 8435 reference material was obtained from the Central Science Laboratory (CSL), York. Several liquid and dried milk samples were obtained from local Tesco and Safeway stores.

Two dried milk samples were supplied by British Nuclear Fuels Ltd (BNFL): a sample of unknown ${ }^{129}$ I content but believed to be below $0.01 \mathrm{ng} \mathrm{g}^{-1}$ in the liquid milk, and a further sample which had been spiked with $1 \mu \mathrm{g} \mathrm{L}^{-1}$ of ${ }^{129} \mathrm{I}$, then freeze-dried to give a ${ }^{129} \mathrm{I}$ concentration of $8 \mathrm{ng} \mathrm{g}^{-1}$.

Reagents for the digestion of the milk powder samples were purchased as follows: tetramethylammonium hydroxide (TMAH) from Apollo (Stockport, UK); hydrogen peroxide (20 vol) and Triton-X from Romil Pure Chemistry Ltd. (Cambridge, UK). Further treatment of the digests utilised $O x o n e \circledR$ (potassium hydrogen peroxymonosulfate sulfate) and methyliso-butylketone, both from Aldrich Chemicals (Gilligham, Dorset, UK); methanol, ammonium thiosulfate, sodium chloride, potassium iodide and nitric acid (trace analysis grade) from Fisher Scientific (Loughborough, UK); and toluene and from Lancaster (Morecambe, Lancs, UK).

OnGuard- $\mathrm{H}^{\mathrm{TM}}$ ion exchange cartridges (Dionex, Camberley, UK) were used for iodine preconcentration, along with palladium nitrate (Avocado, Heysham, UK) and calcium standard solution (1000 $\mu \mathrm{g} \mathrm{mL}^{-1}$ ) (Fisher Scientific, Loughborough, UK). All solutions were made up using deionised water (18.2 M 2 ) (Elga Maxima, Prima Systems, UK). 
The ICP-MS instrument was set up using a multi-element tune solution supplied by SPEX Chemicals (Metuchen, NJ, USA). Calibration standards were freshly prepared from purchased $1000 \mu \mathrm{g} \mathrm{mL}^{-1}$ standard solutions: iodide from SPEX Certiprep (Metuchen, NJ, USA), and molybdenum and antimony (internal standard) from Fisher Scientific (Loughborough, UK).

\section{Digestion Procedure}

500mg dried milk (or $3 \mathrm{~g}$ liquid milk) was weighed into a centrifuge tube. To the dried sample, $3 \mathrm{~mL}$ water was added and mixed well by shaking. $4 \mathrm{~mL}$ each of tetramethylammonium hydroxide (TMAH, 25\%), Triton X-100 (surfactant, $5 \% \mathrm{w} / \mathrm{v}$ ) and $\mathrm{H}_{2} \mathrm{O}_{2}(20$ vol) were then added. The tube was placed in a water bath at $70^{\circ} \mathrm{C}$ for 2 hours, agitating on a vortex mixer every $10-15 \mathrm{~min}$. Following this, the digest was made up to $20 \mathrm{~mL}$ with water, including the addition of $1 \mathrm{~mL}$ of $400 \mu \mathrm{g} \mathrm{L}{ }^{-1} \mathrm{Sb}$ solution as internal standard, shaking to mix. The tube was placed in a centrifuge and spun at $\sim 5000 \mathrm{rpm}$ for $5 \mathrm{~min}$. This procedure was found to give a clear, stable solution that could be nebulised continuously and stored for several days in a refrigerator without degradation. Procedural blanks were prepared alongside each batch of samples.

\section{Calibration Procedure}

Calibration standards were made up in the ranges $1-100 \mu \mathrm{g} \mathrm{L}^{-1}$ of iodide, and $1-20 \mu \mathrm{g} \mathrm{L}^{-1}$ of molybdenum, each standard solution containing the same concentrations of TMAH, Triton $\mathrm{X}-100$ and $\mathrm{Sb}$ as the digests. A calibration curve of ${ }^{127} \mathrm{I} /{ }^{121} \mathrm{Sb}$ signal ratio versus iodine concentration was then used for quantification of ${ }^{127} \mathrm{I}$ in the digests. Molybdenum was quantified in the digests via calibration curves of ${ }^{98} \mathrm{Mo} /{ }^{121} \mathrm{Sb}$ (standard mode) or ${ }^{128} \mathrm{MoO}_{2} /{ }^{121} \mathrm{Sb}$ (collision-reaction cell mode) versus molybdenum concentration.

\section{Pre-concentration Procedures}

Using oxidation/solvent extraction 
The milk powder was digested as above, but excluding the addition of internal standard. The digest $(20 \mathrm{~mL})$ was then taken down to $\mathrm{pH} 2$ via drop-wise addition of conc. $\mathrm{HNO}_{3}$. Oxone ${ }^{\circledR}$ $(0.2 \mathrm{~g})$ and toluene $(5 \mathrm{~mL})$ were added simultaneously as soon as $\mathrm{pH} 2$ was reached, and the vessel stirred using a vortex mixer for around $5 \mathrm{~min}$. The mixture was spun on a centrifuge for a further 3 min to separate the layers; the organic layer was collected and the aqueous layer discarded.

Aqueous ammonium thiosulfate, $0.1 \mathrm{M}(2 \mathrm{~mL})$ was added to the organic layer and the mixture stirred on a vortex mixer for 5 min. Finally, the mixture was spun on a centrifuge ( $5000 \mathrm{rpm})$ and the aqueous layer removed for analysis.

In establishing the above procedure, the effect of using $O x o n e \circledR$ as an oxidising agent for iodide was studied. UV-visible spectra of solutions of potassium iodide $(0.3 \mathrm{mM})$, acidified to $\mathrm{pH} 2$ with sulfuric acid, were recorded at measured time intervals after addition of Oxone® $(40 \mu \mathrm{L}$ of $1 \%$ or $2 \%$ solution), to monitor the presence of iodine species via the characteristic absorbance wavelengths of $\mathrm{I}_{2}(460 \mathrm{~nm}) \mathrm{I}_{3}^{-}(290$ and $350 \mathrm{~nm})$ and $\mathrm{I}^{-}(226 \mathrm{~nm})$.

\section{Using a cation-exchange column:}

An OnGuard- $\mathrm{H}^{\mathrm{TM}}$ cartridge was loaded with $\mathrm{Pd}^{2+}$ by passing palladium nitrate solution (100 $\mu \mathrm{gL}^{-1}, 8 \mathrm{~mL}$ ) through the cartridge. Following this, $13 \mathrm{~mL}$ of an aqueous solution containing $500 \mu \mathrm{g} \mathrm{L}^{-1}$ iodide and $50 \mu \mathrm{g} \mathrm{mL}^{-1} \mathrm{Ca}^{2+}$ was passed thorough the cartridge. The percentage of applied palladium and iodide retained on the cartridge was monitored by ICP-MS determination of these elements in the eluent. The cartridge was washed with methanol, before applying a solution of ammonium thiosulfate $(0.01 \mathrm{M}, 0.5 \mathrm{~mL})$ to the cartridge to elute the iodide (as palladium iodide). This procedure was tried using the milk digest solution in place of the aqueous iodide/calcium solution. 


\section{Results and Discussion}

\section{Determination of ${ }^{127}$ I in milk powder}

The basic digestion procedure, using TMAH, Triton- $\mathrm{X}$ and hydrogen peroxide as described above, was found to successfully digest the milk samples with the quantification of ${ }^{127}$ I in the CRMs being in close agreement with certified values, as shown in Table 2. The limit of detection was blank-limited at about $0.1 \mu \mathrm{g} \mathrm{g}^{-1}$ in the milk powder.

Table 2. Determination of ${ }^{127} I$ in milk powder samples

\begin{tabular}{|l|l|l|}
\hline Reference Material & Found Value ${ }^{*}\left(\mu \mathbf{g ~ g}^{-1}\right)$ & Certified Value $\left(\mu \mathbf{g ~ g}^{-1}\right)$ \\
\hline BCR063R $(n=6)$ & $0.75 \pm 0.12$ & $0.81 \pm 0.05$ \\
\hline NIST8435 $(n=4)$ & $2.64 \pm 0.40$ & $2.3 \pm 0.4$ \\
\hline
\end{tabular}

${ }^{*}$ Found values are expressed as mean $\pm 3 \times$ standard deviation

This sample preparation procedure could have wider application, including the determination of metals in oxy-anions (e.g. $\mathrm{Cr}(\mathrm{VI})$, As, Se, Mo), and other trace metals by addition of EDTA to maintain them in solution at the alkaline $\mathrm{pH}$ used [23]. Molybdenum was quantified in the milk digests, as described in the next section, but other elements were not determined in this work.

\section{Removal of $\mathrm{Xe}^{+}$interference}

In order to measure ${ }^{129} \mathrm{I}$ by ICP-MS it was necessary to remove $\mathrm{Xe}^{+}$interference and this was successfully carried out for aqueous samples, where the background $\mathrm{m} / \mathrm{z} 129$ signal was effectively eliminated with $\mathrm{He}\left(1.0 \mathrm{~mL} \mathrm{~min}^{-1}\right)$ and $\mathrm{O}_{2}\left(0.6 \mathrm{~mL} \mathrm{~min}{ }^{-1}\right)$ in the collision/reaction cell, due to the charge transfer reaction noted previously (equation (2)).

The milk digests however produced a sizeable signal at $\mathrm{m} / \mathrm{z} 129$. This was not due to residual $\mathrm{Xe}^{+}$(as the signal for ${ }^{131} \mathrm{Xe}$ was virtually zero), but was found to be due to the almost 
quantitative conversion of $\mathrm{Mo}^{+}$to $\mathrm{MoO}_{2}{ }^{+}$in milk powder digests with $\mathrm{O}_{2}$ in the cell. This was confirmed by running a standard $\left(20 \mu \mathrm{g} \mathrm{L}^{-1}\right)$ Mo solution in standard and CCT modes.

Standard mode signals for Mo isotopes at $\mathrm{m} / \mathrm{z}$ 92, 94, 95, 96, 97, 98 and 100 disappeared in CCT mode to be replaced by signals (in the same isotopic proportions) at $\mathrm{m} / \mathrm{z} 124,126,127$, 128, 129, 130 and 132, as shown in Figure 1.

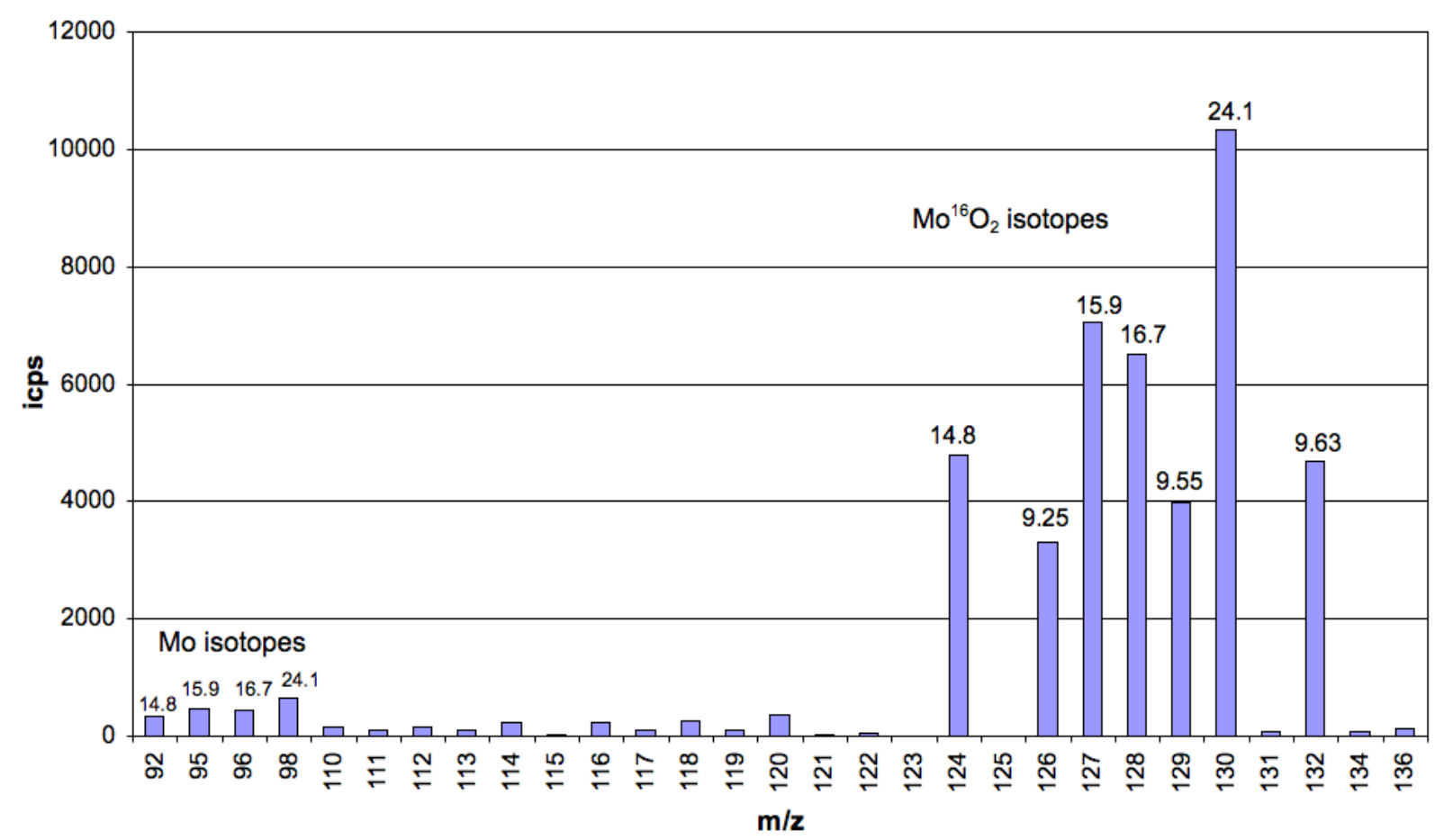

Figure 1. $20 \mu \mathrm{g} \mathrm{L}^{-1}$ Mo standard in water: ICP-MS with CCT using $\mathrm{He}+\mathrm{O}_{2}$ optimised for Xe removal; labels are natural abundances of Mo isotopes.

This formation of $\mathrm{MoO}_{2}{ }^{+}$is consistent with the findings of Koyanagi et al. [24] who showed that $\mathrm{Mo}^{+}$ions produced in an ICP source and thermalised by collision with $\mathrm{Ar}$ or $\mathrm{He}$ atoms react with $\mathrm{O}_{2}$ at room temperature in a two stage reaction:

$$
\begin{aligned}
& \mathrm{Mo}^{+}+\mathrm{O}_{2} \rightarrow \mathrm{MO}^{+}+\mathrm{O} \\
& \mathrm{MoO}^{+}+\mathrm{O}_{2} \rightarrow \mathrm{MoO}_{2}^{+}+\mathrm{O}
\end{aligned}
$$

The signal at $\mathrm{m} / \mathrm{z} 128$ was used to quantify Mo in the two milk CRMs, the unspiked BNFL sample and a Safeways dried milk sample (selected at random), and the results compared with values obtained by measuring ${ }^{98} \mathrm{Mo}$ (and ${ }^{97} \mathrm{Mo}$ ) in the same digests in standard (non- 
$\mathrm{CCT}$ ) mode. In all cases ${ }^{121} \mathrm{Sb}$ was used as the internal standard for the determinations. The results are summarized in Table 3 and it can be seen that there is good agreement between the Mo values recorded in the two instrumental modes and also that the results for the CRMs are in acceptable agreement with the certified value for NIST8435. The detection limit for Mo was $0.01 \mu \mathrm{g} \mathrm{g}^{-1}$ in the milk powder in both standard and CCT modes.

Table 3. Determination of molybdenum in milk powder samples in standard and CCT modes

\begin{tabular}{|l|l|l|l|}
\hline Sample & $\begin{array}{l}\text { Mo content }\left(\mu \mathrm{g} \mathrm{g}^{-1}\right) \\
\text { from }{ }^{98} \mathrm{Mo}^{121} \mathrm{Sb} \\
(\text { standard mode) }\end{array}$ & $\begin{array}{l}\text { Mo content }\left(\mu \mathrm{g} \mathrm{g}^{-1}\right) \\
\text { from }{ }^{128} \mathrm{MoO}_{2} /^{121} \mathrm{Sb} \\
(\text { CCT mode)* }\end{array}$ & $\begin{array}{l}\text { Certified (c) values } \\
\left(\mu \mathrm{g} \mathrm{g}^{-1}\right)\end{array}$ \\
\hline BCR063R & $0.23 \pm 0.03$ & $0.23 \pm 0.08$ & $\mathrm{n} / \mathrm{a}$ \\
\hline NIST8435 & $0.22 \pm 0.04$ & $0.24 \pm 0.03$ & $0.29 \pm 0.13(c)$ \\
\hline BNFL (unspiked) & $0.40 \pm 0.10$ & $0.37 \pm 0.11$ & $\mathrm{n} / \mathrm{a}$ \\
\hline Safeways dried milk & $0.31 \pm 0.13$ & $0.27 \pm 0.16$ & $\mathrm{n} / \mathrm{a}$ \\
\hline
\end{tabular}

* Experimental values are expressed as mean $\pm 3 \times$ standard deviation of results from 3 separate digests of each sample. Quantitation using ${ }^{97} \mathrm{Mo} /{ }^{121} \mathrm{Sb}$ gave the same results as ${ }^{98} \mathrm{Mo} /{ }^{121} \mathrm{Sb}$.

As can be seen from Table 3, Mo concentrations in the milk samples were all similar and in the range $0.2-0.4 \mu \mathrm{g} \mathrm{g}^{-1}\left(5-10 \mu \mathrm{g} \mathrm{L}^{-1}\right.$ in the digest solution). This is not high enough to cause noticeable interference with the measurement of ${ }^{127} \mathrm{I}$ in milk, though may be significant (5 - 10\% increase in $\mathrm{m} / \mathrm{z} 127$ signal) for iodine levels less than $1 \mathrm{mg} \mathrm{kg}^{-1}$ in milk powder. However, interference on ${ }^{129} \mathrm{I}$ at low levels would clearly be severe, as can be seen in Table 4 which shows typical signal levels obtained for standards and digest solutions, with and without the use of gas in the collision cell.

Attempts were made to adjust conditions in the cell to try to remove as much Xe as possible whilst minimising production of $\mathrm{MoO}_{2}{ }^{+}$and maintaining a strong iodine signal at $\mathrm{m} / \mathrm{z} 127$. A mixed standard solution containing $10 \mu \mathrm{g} \mathrm{L}^{-1}$ molybdenum and $20 \mu \mathrm{g} \mathrm{L}^{-1}$ iodine was 
Table 4. Typical signals (counts per second) for standards and digest solutions. Standard conditions employed no gas in cell; $\mathrm{CCT}$ used $\mathrm{He}+\mathrm{O}_{2}$ at $1.0+0.6 \mathrm{~mL} \mathrm{~min}^{-1}$.

\begin{tabular}{|l|l|l|l|l|l|l|}
\hline & \multicolumn{2}{|c|}{$\mathrm{m} / \mathrm{z} 127$} & \multicolumn{2}{c|}{$\mathrm{m} / \mathrm{z} 129$} & \multicolumn{2}{c|}{$\mathrm{m} / \mathrm{z} 131$} \\
\hline $\begin{array}{l}1 \mu \mathrm{g} \mathrm{L}^{-1} \text { lodine } \\
\text { solution }\end{array}$ & Standard & CCT & Standard & CCT & Standard & CCT \\
\hline $\begin{array}{l}\text { Milk powder } \\
\text { digest solution }\end{array}$ & $\begin{array}{l}12,000 \\
\mathrm{~g} \mathrm{~L} \mathrm{~L}^{-1} \text { iodine }\end{array}$ & $\begin{array}{l}\mu, 000 \\
\mathrm{~g} \mathrm{~L}^{-1} \text { iodine }\end{array}$ & 3,000 & 50 & 2,800 & 10 \\
\hline $\begin{array}{l}10 \mu \mathrm{g} \mathrm{L}^{-1} \mathrm{Mo} \\
\text { solution }\end{array}$ & Blank level & 3,000 & 2,400 & 2,400 & 1,900 & 30 \\
\hline
\end{tabular}

investigated using $\mathrm{CCT}$, varying gas and pole bias conditions. $\mathrm{Xe}^{+}$was tracked by monitoring the signal at $\mathrm{m} / \mathrm{z} 131$ and the $126 / 97$ signal ratio monitored conversion of $\mathrm{Mo}^{+}$to $\mathrm{MoO}_{2}{ }^{+}$. Very little improvement was found by varying the pole bias conditions using $\mathrm{He}$ and $\mathrm{O}_{2}$ gases, and the use of $\mathrm{He}+\mathrm{H}_{2}$ over a wide range of flow rates in the cell failed to provide any effective reduction in Xe interference (in contrast to results reported by Becker [25]), as the 127/131 signal ratio remained the same as with no gas in the cell. It was concluded that separation and pre-concentration of iodine in the digests would be needed to determine low levels $\left(<0.01 \mathrm{ng} \mathrm{g}^{-1}\right)$ of ${ }^{129}$.

\section{Pre-concentration of iodine by trapping on a column}

Initial attempts were made to concentrate and separate the iodide by addition of silver nitrate to precipitate silver halides, followed by filtration, dissolution of silver chloride with ammonium hydroxide and extraction of iodide from the filter with ammonium thiosulfate, but this approach met with little success. It was felt a column technique would be preferable, whereby silver ions on a cation exchange column (OnGuard- $\mathrm{H}^{\mathrm{TM}}$ ) could be used to retain the halides. However, the large excess of chloride in the digests made this problematical due to column overload. It was clear that a column method was needed that would trap iodide but not chloride. 
To this end, the use of a $\mathrm{Pd}^{2+}$-loaded column was investigated, to make use of the insolubility of $\mathrm{Pdl}_{2}$ compared to the solubility of $\mathrm{PdCl}_{2}$. Passing $\mathrm{Pd}\left(\mathrm{NO}_{3}\right)_{2}$ solution $\left(100 \mu \mathrm{g} \mathrm{mL}^{-1}, 8 \mathrm{~mL}\right)$ through an OnGuard- $\mathrm{H}^{\mathrm{TM}}$ cartridge resulted in effective saturation of available sites with $\mathrm{Pd}^{2+}$. However, on passing through aqueous solutions of potassium iodide, it was found that iodide was poorly retained on the cartridge, indicating that little $\mathrm{Pdl}_{2}$ was being formed. This problem was alleviated by the addition of $\mathrm{Ca}^{2+}$ which by competing for binding sites appeared to mobilise the $\mathrm{Pd}^{2+}$ making it available for $\mathrm{Pdl}_{2}$ formation. On passing $13 \mathrm{~mL}$ of an aqueous solution of $500 \mu \mathrm{g} \mathrm{L}^{-1} \mathrm{I}^{-}$plus $50 \mu \mathrm{g} \mathrm{mL}^{-1} \mathrm{Ca}^{2+}$ through the $\mathrm{Pd}^{2+}$-loaded cartridge it was found that $>97 \%$ of the iodide was retained on the cartridge; for lower levels of iodide $\left(100 \mu \mathrm{g} \mathrm{L}^{-1} \mathrm{I}^{-}\right)$ the retention was a little less efficient, but still $>80 \%$.

It was found that a $0.01 \mathrm{M}$ solution of ammonium thiosulfate was very efficient at eluting the $\mathrm{Pdl}_{2}$ from the cartridge in a small volume (the characteristic brown colour was seen within the first $0.5 \mathrm{~mL}$ of eluent, whereafter the eluent ran clear) whilst avoiding the column degradation observed with higher thiosulfate concentrations. Thus a high pre-concentration factor could be achieved. It was further found that methanol did not elute any of the iodide; thus methanol could be used as a wash step between loading and eluting the column, to remove any unwanted organic matter.

It was hoped that this success at pre-concentrating iodine (as iodide) in aqueous samples using a $\mathrm{Pd}^{2+}$-loaded cartridge could be translated to the milk digest samples. This optimism was fuelled by the fact that the milk samples already contained sufficient calcium to facilitate retention on the cartridge, and the cartridges have a quoted $\mathrm{pH}$ working range of $0-14$ and hence would not be adversely affected by the strongly alkaline digests. However, the method did not work with the milk digests. The palladium was stripped from the cartridge on application of the digest solution and consequently iodide was not retained; it is likely that the $\mathrm{Pd}^{2+}$ was displaced by the tetramethylammonium ion present in large excess from the digestion reagent. 
It was thought that it might be possible to form $\mathrm{Pdl}_{2}$ within the digest solution simply on addition of a large molar excess of $\mathrm{Pd}\left(\mathrm{NO}_{3}\right)_{2}$. However, experiments such as a Bjerrom plot and speciation simulations using CHESS (Chemical Equilibrium of Species and Surface environmental speciation modelling software, ARMINES, Fontainebleu, France) showed that, at the strongly alkaline $\mathrm{pH}$ of the digest solution, $\mathrm{Pd}^{2+}$ does not exist and that the dominant species will in fact be $\mathrm{PdO}(\mathrm{aq})$ and $\mathrm{Pd}(\mathrm{OH})_{2}$. The $\mathrm{Pd}^{2+}$ ion will only exist in the solution if the $\mathrm{pH}<2$. This is important since it would suggest that the formation of $\mathrm{Pdl}_{2}$ would not be ionic and would not occur rapidly; instead the reaction would have to proceed by a ligand substitution reaction and could potentially be very slow.

\section{Pre-concentration of iodine by oxidation/solvent extraction}

As an alternative to a column separation, solvent extraction was tried, extracting the analyte as molecular iodine from an acidified digest $\left(\mathrm{HNO}_{3}\right.$ added to $\left.\mathrm{pH} 2\right)$, using toluene as the solvent. The non-polar, but highly polarisable, molecular iodine should be extracted into the toluene layer. Ammonium thiosulfate or TMAH could then be used to back-extract the iodine as iodide into a small volume of aqueous solution. However, very low and variable amounts of iodine were extracted from digests (as measured by ICP-MS), despite various modifications to the conditions (e.g. $\mathrm{pH}$ adjustments, omission of Triton-X, addition of $\mathrm{NaCl}$ ) to try to improve the separation and extraction process.

The $\mathrm{I}_{2}$ may well have been lost through one or more of a variety of other reactions which may have been favoured under the conditions used, such as:

- Formation of $\mathrm{I}_{2}-\mathrm{Cl}^{-}$(due to high $\mathrm{Cl}^{-}$in digests)

- Interaction of $\mathrm{I}_{2}$ with $\mathrm{H}_{2} \mathrm{O}$, e.g.

$$
\mathrm{I}_{2}+\mathrm{H}_{2} \mathrm{O} \rightleftharpoons \mathrm{HOI}+\mathrm{I}^{-}+\mathrm{H}^{+}
$$

- Loss of $\mathrm{I}_{2}$ via disproportionation to $\mathrm{I}^{-}$and $\mathrm{IO}_{3}{ }^{-}$

- Formation of $\mathrm{I}_{3}^{-}$: 


$$
\mathrm{I}_{2}+\mathrm{I}^{-} \rightleftharpoons \mathrm{I}_{3}^{-}
$$

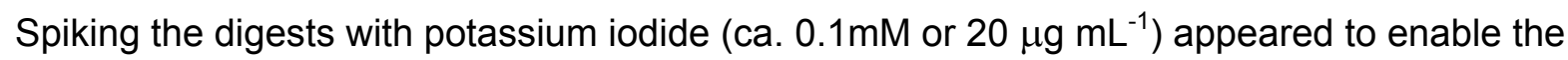
formation of molecular iodine and its subsequent reduction to iodide to be visibly tracked although later studies showed that the visible species was almost certainly $\mathrm{I}_{3}{ }^{-}$. In addition, the $\mathrm{H}_{2} \mathrm{O}_{2} / \mathrm{HNO}_{3}$ in the digest may have provided insufficient oxidation potential to form $\mathrm{I}_{2}$ reliably.

The formation of $\mathrm{I}_{3}^{-}$(equation (4)) was clearly shown by measuring UV-visible spectra of acidified solutions ( $\mathrm{pH} 1-2)$ containing potassium iodide $(2-10 \mathrm{mM})$ and hydrogen peroxide (20 vol, 4mL) in $20 \mathrm{~mL}$ water, which showed sizeable peaks at $350 \mathrm{~nm}$ and $460 \mathrm{~nm}$ (Figure 2 (a),(b)) indicating the presence of $\mathrm{I}_{3}{ }^{-}$and $\mathrm{I}_{2}$, thus showing oxidation of the iodide to iodine, with significant $\mathrm{I}_{3}^{-}$also produced.

The size of the $\mathrm{I}_{2}$ peak $(460 \mathrm{~nm})$ decreased at $\mathrm{pH}>1$ and at $\mathrm{pH} 3$ and higher the $\mathrm{I}_{2}$ peak disappeared, though the $\mathrm{I}_{3}{ }^{-}$peak could be seen up to $\mathrm{pH} 6$, indicating that any $\mathrm{I}_{2}$ produced under these less acidic conditions appeared to be complexed with the large excess of $\mathrm{I}^{-}$. (Note that the large peak at ca. $300 \mathrm{~nm}$ is due to the nitrate ion of the nitric acid used to acidify the solution). Further evidence for the formation of $\mathrm{I}_{3}{ }^{-}$in oxidised iodide solutions was found during studies into a possible method for removing trace iodine contamination from the TMAH reagent by a polarographic method. Electrochemical oxidation of potassium iodide (in deionised water with $0.1 \mathrm{M} \mathrm{KCl}$ electrolyte) produced a straw-coloured liquid with a UVvisible spectrum having characteristic $\mathrm{I}_{3}{ }^{-}$peaks $(290 \mathrm{~nm}$ and $350 \mathrm{~nm})$ but no $\mathrm{I}_{2}$ peak at 460 nm (Figure 2 (c)). 
(a)

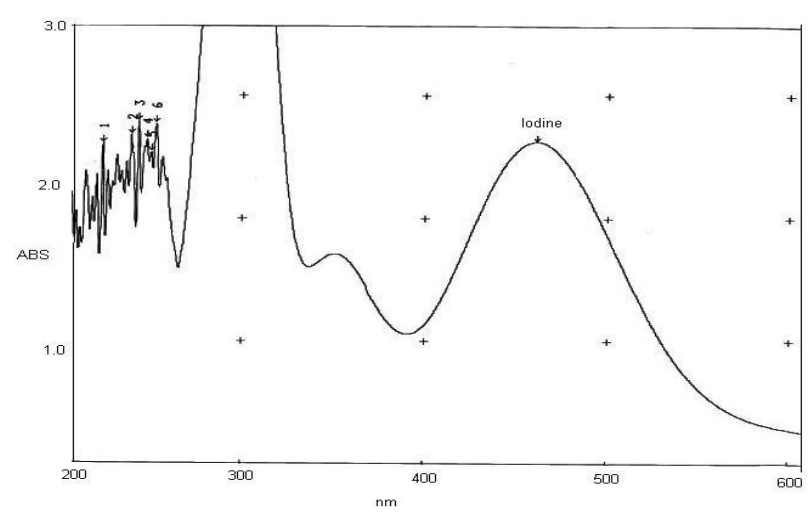

(b)

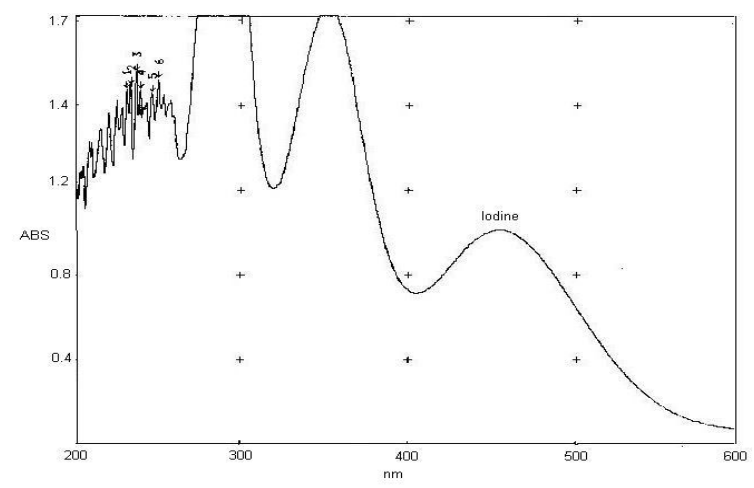

(c)

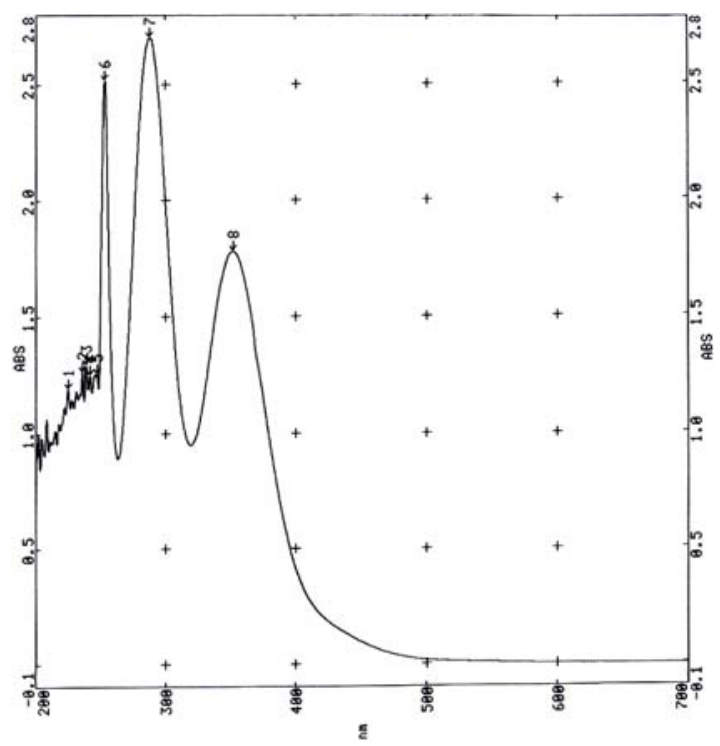

Figure 2: UV-visible absorbance spectra of potassium iodide solution after oxidation (a) with $\mathrm{H}_{2} \mathrm{O}_{2}$ at pH 1, (b) with $\mathrm{H}_{2} \mathrm{O}_{2}$ at pH 2.2 and (c) electrochemically in water $+0.1 \mathrm{M}$ $\mathrm{KCl}$. Peaks indicate the presence of $\mathrm{I}_{3}^{-}(290 \& 350 \mathrm{~nm})$ in $(\mathrm{a}-\mathrm{c})$ and $\mathrm{I}_{2}(460 \mathrm{~nm})$ in $(\mathrm{a}, \mathrm{b})$.

\section{Use of Oxone ${ }^{\circledR}$ as oxidising agent}

As oxidation to $I_{2}$ may not have been taking place reliably in the acidified digest, it was felt that a more powerful oxidising agent than $\mathrm{H}_{2} \mathrm{O}_{2}+\mathrm{HNO}_{3}$ in the digest was required. Oxone ${ }^{\circledR}$ (Dupont Chemicals) has as its active ingredient potassium monopersulfate $\left(\mathrm{KHSO}_{5}\right)$ which is present in the triple salt potassium hydrogen peroxymonosulfate sulfate $\left(2 \mathrm{KHSO}_{5} \cdot \mathrm{KHSO}_{4} \cdot \mathrm{K}_{2} \mathrm{SO}_{4}\right.$, molecular weight 614.7$)$ [26]. Oxone $₫$ dissolved in water is naturally acidic ( $\mathrm{pH} 2.3$ for $1 \%$ solution, $\mathrm{pH} 2.0$ for $3 \%$ solution), and undergoes reduction as shown in the following half reaction: 


$$
\mathrm{HSO}_{5}^{-}+2 \mathrm{H}^{+}+2 \mathrm{e}^{-} \rightarrow \mathrm{HSO}_{4}^{-}+\mathrm{H}_{2} \mathrm{O} \quad \mathrm{E}^{0}=+1.44 \mathrm{~V}
$$

and thus the reduction potential is sufficiently positive to enable Oxone $₫$ to reliably and completely oxidise $\mathrm{I}^{-}$to $\mathrm{I}_{2}$ at room temperature in acid solution, via the reaction:

$$
\mathrm{HSO}_{5}^{-}+2 \mathrm{H}^{+}+2 \mathrm{I}^{-} \rightarrow \mathrm{HSO}_{4}^{-}+\mathrm{I}_{2}+\mathrm{H}_{2} \mathrm{O}
$$

By monitoring the characteristic UV-visible absorbance wavelengths of $\mathrm{I}_{2}(460 \mathrm{~nm}) \mathrm{I}_{3}{ }^{-}(290$ and $350 \mathrm{~nm})$ and $\mathrm{I}^{-}(226 \mathrm{~nm})$ in test solutions, Gazda et al.[27] showed that Oxone $®$ treatment was capable of converting not only $\mathrm{I}^{-}$but also $\mathrm{I}_{3}{ }^{-}$to $\mathrm{I}_{2}$, probably as a result of oxidation of all available $\mathrm{I}^{-}$causing a shift in the equilibrium of equation (4).

To investigate the effect of using Oxone ${ }^{\circledR}$ instead of $\mathrm{H}_{2} \mathrm{O}_{2}$ as an oxidising agent for iodide, Oxone ${ }^{\circ}(1.25 \mathrm{mM})$ was added to $20 \mathrm{~mL}$ of potassium iodide solution $(5 \mathrm{mM})$. The UVvisible spectrum of the solution was measured at 10 minute intervals. The spectra were very different from those observed using $\mathrm{H}_{2} \mathrm{O}_{2}$ at the same $\mathrm{pH}(\mathrm{pH} 2)$. Only the $\mathrm{I}_{2}$ peak $(460 \mathrm{~nm})$ was evident; the $\mathrm{I}_{3}{ }^{-}$peaks were entirely absent, and the $\mathrm{I}_{2}$ peak gradually decreased over time, disappearing completely an hour after the Oxone® was first added (Figure 3).

A possible reason for this decline in $\mathrm{I}_{2}$ could be due to the formation of volatile $\mathrm{HI}$ in acidic solution, or reaction with water to produce $\mathrm{HOI}$ and $\mathrm{I}^{-}$(equation (3)). Although Oxone ${ }^{\circledR}$ has sufficient oxidation potential in principle to convert $\mathrm{I}_{2}$ to $\mathrm{IO}_{3}{ }^{-},\left(\mathrm{E}^{0}=+1.21 \mathrm{~V}\right)$, in practice this reaction is not favoured at low $\mathrm{pH}$.

Acidic conditions are necessary for the Oxone ${ }^{\circledR}$ to work (equation (5)) and this was confirmed in practice. A $1 \%$ aqueous solution of $\mathrm{Oxone} 囚$ had a natural $\mathrm{pH}$ of 2 and adjusting to alkaline $\mathrm{pH}$ meant that the iodide was not oxidised. 


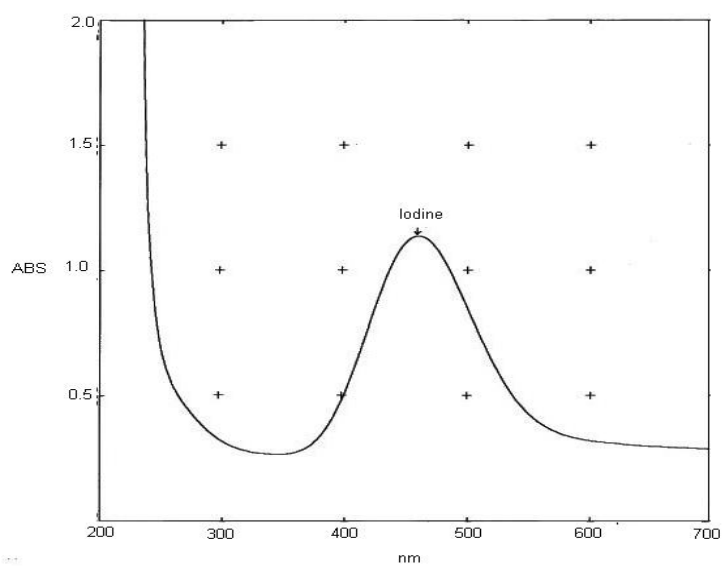

(a)

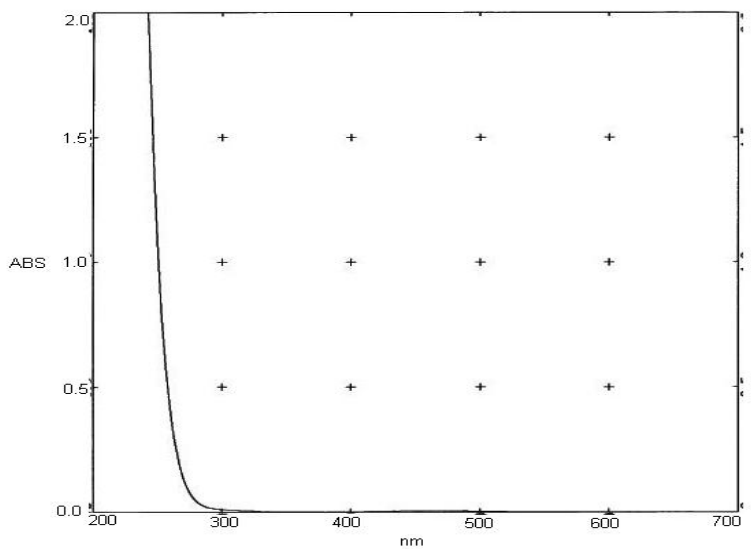

(b)

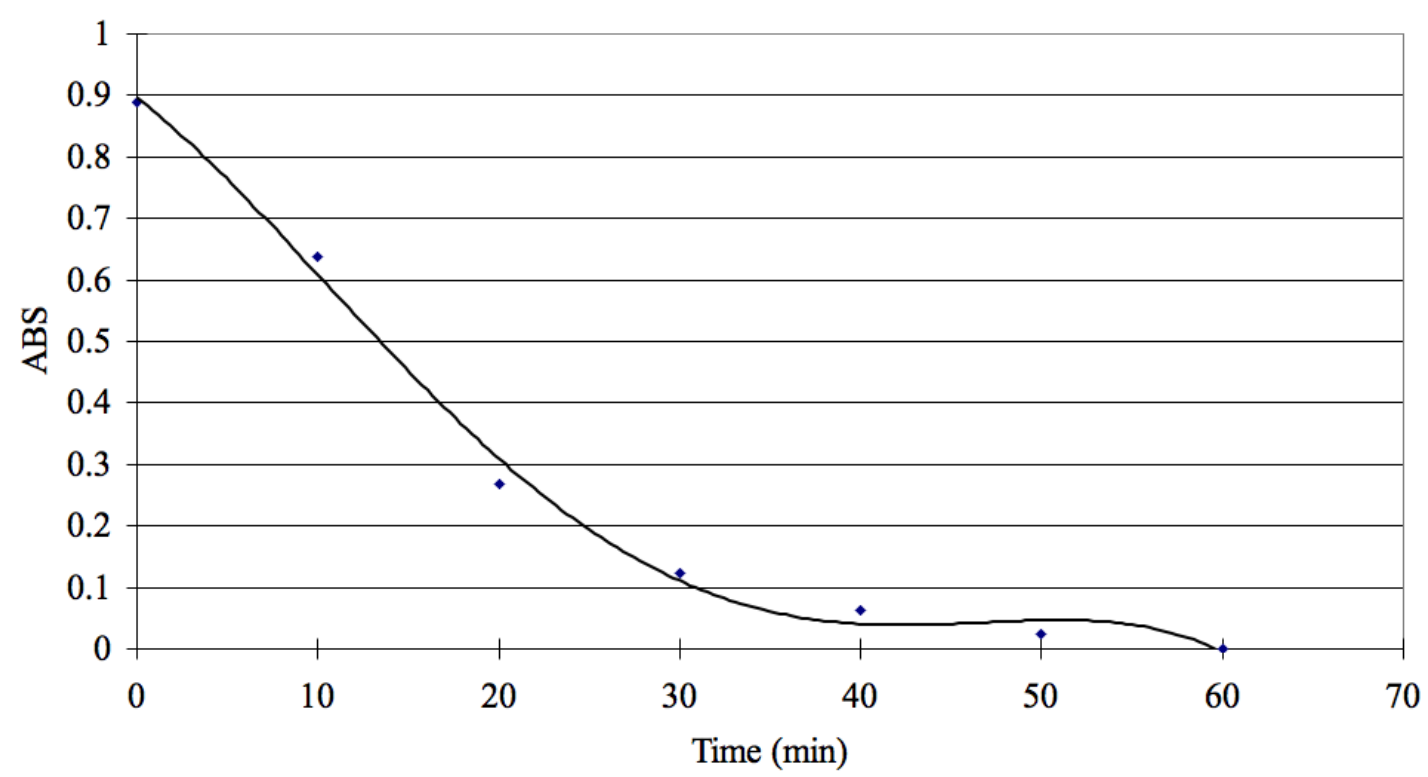

Figure 3: UV-visible spectra showing the gradual disappearance of $I_{2}$ produced in acidified potassium iodide solution (a) immediately after adding Oxone ${ }^{\circledR}$ and (b) one hour later; (c) shows the decline in absorbance at $460 \mathrm{~nm}\left(I_{2}\right.$ peak) over the one-hour period.

Subsequent experiments with varying concentrations of potassium iodide showed that a concentration of $50 \mu \mathrm{g} \mathrm{mL}^{-1}(0.3 \mathrm{mM})$, acidified to $\mathrm{pH} 2$ with sulfuric acid (to avoid interfering nitrate peaks) produced a very large but on-scale iodide peak and such a solution was used to follow the oxidation process, by adding Oxone ${ }^{\circledR}$ directly into the quartz cuvette and observing the change in the spectrum over time. The UV-visible spectrum of Oxone $₫$ solution alone showed only one peak at $202 \mathrm{~nm}$; thus any un-reacted Oxone® would not mask the peaks due to iodine species. 
After measuring the spectrum of the $50 \mu \mathrm{g} \mathrm{mL}^{-1}$ acidified potassium iodide solution, $40 \mu \mathrm{L}$ of Oxone $\circledR$ solution $(1 \%)$ was added and the spectrum recorded immediately, then again after 5 min and $10 \mathrm{~min}$. On addition of Oxone ${ }^{\circledR}$, the iodide peak $(226 \mathrm{~nm})$ reduced in size and small peaks at $290 \mathrm{~nm}, 350 \mathrm{~nm}$ and $460 \mathrm{~nm}$ appeared. However, after $5 \mathrm{~min}$, the peaks at 290 and $350 \mathrm{~nm}\left(\mathrm{I}_{3}{ }^{-}\right)$had more than doubled in size, whilst that at $460 \mathrm{~nm}\left(\mathrm{I}_{2}\right)$ remained very small. The spectrum after 10 min remained virtually the same with a very slight further reduction in the iodide peak at $226 \mathrm{~nm}$ (see Figure 4a).

The above experiment was repeated, but this time doubling the amount of Oxone® added. This time the iodide peak essentially disappeared on addition of $O x o n e \circledast$, and three small peaks at 290, 350 and $460 \mathrm{~nm}$ appeared, but after 5 min the first two of these had gone, leaving a single peak at $460 \mathrm{~nm}$, which almost doubled in size from 0 - 5 min before gradually decreasing but remaining at about two-thirds of its maximum height after an hour (see Figure 4b). This indicated that the higher level of Oxone ${ }^{\circledR}$ had successfully oxidised the $\mathrm{I}^{-}$to $\mathrm{I}_{2}$, and the $\mathrm{I}_{3}{ }^{-}$formed (according to equation (4)) had also been quantitatively converted to $\mathrm{I}_{2}$, as previously reported [27].

The above experiments showed that if insufficient $O x \operatorname{xone}^{\circledR}$ were added, such that unoxidised iodide remained, any $\mathrm{I}_{2}$ formed would complex with the remaining $\mathrm{I}^{-}$to leave $\mathrm{I}_{3}^{-}$as the dominant oxidised species. Therefore Oxone ${ }^{\circledR}$ should be added in excess to a solution at $\mathrm{pH} 2$ to ensure quantitative conversion to $\mathrm{I}_{2}$.

Whilst the iodine species formed in aqueous iodide solutions treated with Oxone $\circledast$ could usefully be monitored via their UV-visible absorbance profiles, it was not possible to monitor the iodine species in the digest solutions directly by UV-visible spectroscopy, due to large absorbances of other components in the digest matrix masking the iodine peaks. 
(a)

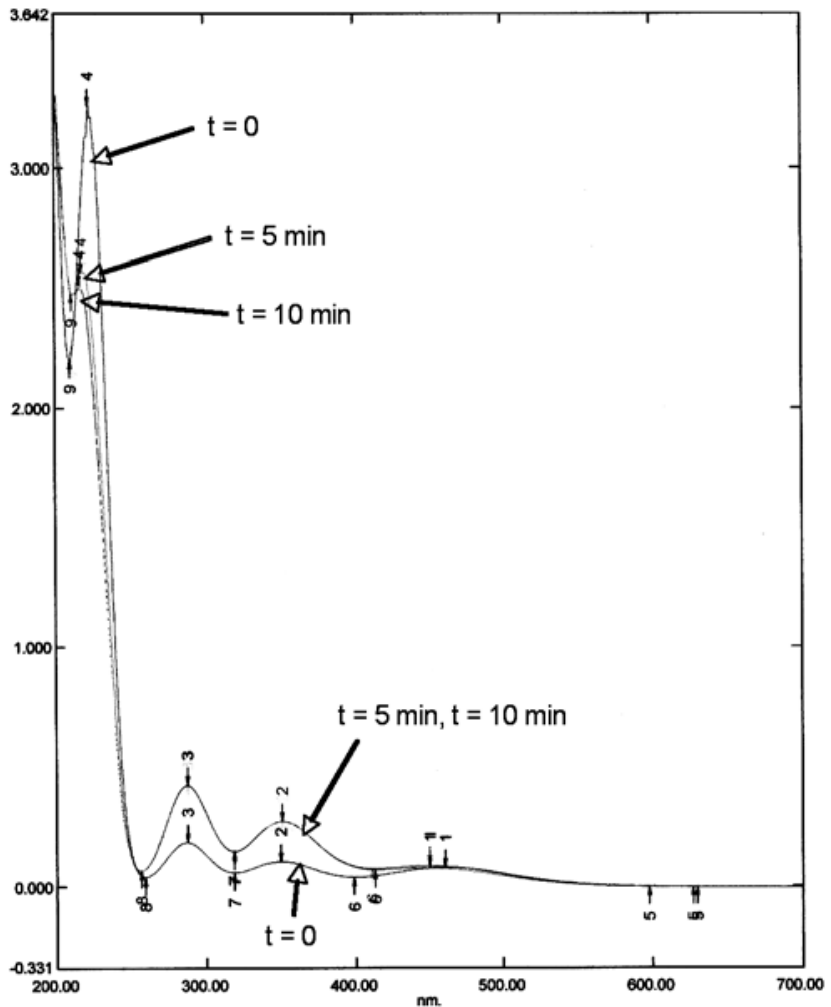

(b)

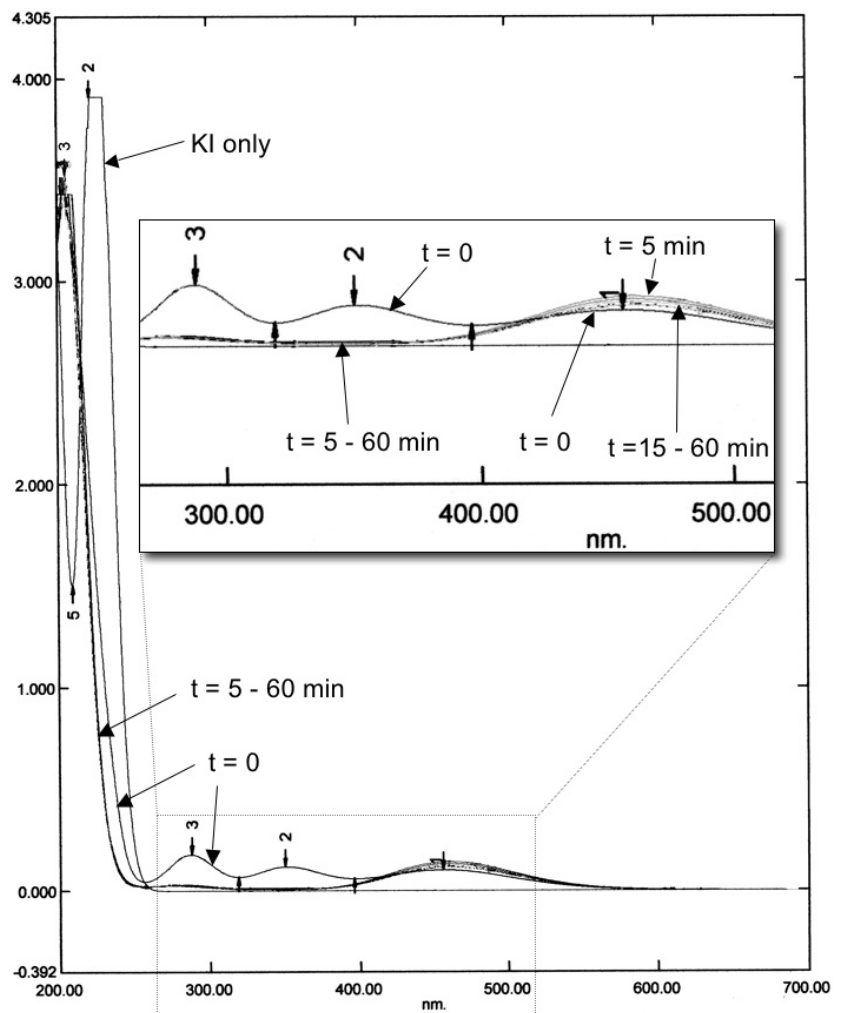

Figure 4: UV-visible spectra showing the effect of treating a $50 \mu \mathrm{g} \mathrm{mL}^{-1}$ solution of acidified potassium iodide ( $\mathrm{pH} 2$ ) in a standard UV cuvette with (a) $40 \mu \mathrm{L}$ of $1 \%$ Oxone ${ }^{\circledR}$ solution and (b) $40 \mu \mathrm{L}$ of $2 \%$ Oxone ${ }^{\circledR}$ solution, where $\mathrm{t}$ is the time period between the addition of Oxone and recording the spectrum (The peak at $\sim 200 \mathrm{~nm}$ is probably due to residual Oxone $\left.{ }^{\circledR}\right)$.

\section{Solvent Extraction following Oxone ${ }^{\circledR}$ oxidation}

Digests of the milk sample spiked with ${ }^{129}$ I were prepared for analysis using the Oxone oxidation/extraction scheme as detailed in the Experimental section. These, along with procedural blanks and un-extracted digests for comparison, were introduced to the ICP-MS, with the collision cell employed as described earlier. The signals at $\mathrm{m} / \mathrm{z} 95,97,126,127$, $128,129,130$ and 131 were measured. By monitoring $\mathrm{m} / \mathrm{z} 131$, it was seen that $\mathrm{Xe}^{+}$had been successfully removed. Monitoring $\mathrm{m} / \mathrm{z}$ 126-130 showed clearly the characteristic pattern of $\mathrm{MoO}_{2}{ }^{+}$for the un-extracted digest, except that the signal at $\mathrm{m} / \mathrm{z} 129$ was higher 
than would be expected from the Mo isotope ratios, indicating that ${ }^{129} \mathrm{I}$ was being detected, albeit largely masked by the $\mathrm{MoO}_{2}{ }^{+}$signal. In principle, the pre-concentration procedure should remove the molybdenum and lead to a ten-fold increase in iodine signals at $\mathrm{m} / \mathrm{z} 127$ and 129 (20 mL digest solution to $2 \mathrm{~mL}$ ammonium thiosulfate extract). Whilst analysis of the pre-concentrated digest showed that the $\mathrm{MoO}_{2}{ }^{+}$interference had been essentially removed, the signal at $\mathrm{m} / \mathrm{z} 129$ was much lower than would be expected for the ${ }^{129}$ I (assuming a concentration factor of 10 ). Moreover the ${ }^{127}$ I signal had only increased by a factor of 3 .

Possible reasons for the poor extraction efficiency can be suggested by considering the stages in the extraction and the possible iodine species formed. In the initial digest, it is assumed that the iodine is present mostly as free iodide [6] and some organic iodine which is released according to

$$
\mathrm{R}-\mathrm{I}+\mathrm{OH}^{-} \rightleftharpoons \mathrm{R}-\mathrm{OH}+\mathrm{I}^{-}
$$

which is heavily biased towards the right hand side of the equilibrium when TMAH is present.

Once the iodide is oxidised to iodine on addition of Oxone ${ }^{\circledR}$ (equation (5)), there is the possibility that it may be complexed by residual organic matter in solution. The addition of a strong complexing agent with a high affinity for iodine might mitigate this effect and aid the extraction of iodine. Polyvinylpyrrolidone (PVP) should fulfil this function, and the yellow colour of the iodine-PVP complex (used as a colorimetric reagent for iodine determination [27]) could aid visual tracking of the extraction.

Alternatively, it has been shown that iodine readily complexes with iodide ions to form $\mathrm{I}_{3}^{-}$. In the presence of a large excess of chloride ions in the digest (of the order of $250 \mu \mathrm{g} \mathrm{mL}^{-1}$ ), $\mathrm{I}_{2} \mathrm{Cl}^{-}$may be formed, thus hampering extraction of $\mathrm{I}_{2}$ into toluene. One solution to this would be to add silver nitrate after the $\mathrm{I}_{2}$ has been formed, to precipitate out the chloride as $\mathrm{AgCl}$ and thus avoid the formation of $\mathrm{I}_{2} \mathrm{Cl}^{-}$. 
Addition of either PVP or silver nitrate to the digests yielded no improvement in extraction efficiency, although the work was hampered by high blanks at m/z 127 and m/z 129 from the addition of the reagents, as seen in the procedural blanks.

\section{Conclusion}

The complex redox chemistry of iodine makes this a difficult element to extract from complex biological matrices and determine at low (sub $\left.\mu \mathrm{g} \mathrm{L}^{-1}\right)$ concentrations, as encountered when monitoring low levels of ${ }^{129} \mathrm{I}$ in milk. This work has yielded a reliable method for the determination of ${ }^{127} \mathrm{I}$ in milk samples (verified with certified reference materials), using alkaline digestion with TMAH and hydrogen peroxide, followed by quadrupole ICP-MS analysis. The digestion method has been successfully applied to the determination of molybdenum in milk and could also be used to prepare biological materials for determination of other anions, e.g. of Se and As and, with the addition of EDTA, trace metals analysis.

Investigation of pre-concentration/extraction techniques to remove the matrix interferences, as well as raising the ${ }^{129}$ I concentration to measurable levels, has resulted in a new method for the separation and pre-concentration of iodide, using a $\mathrm{Pd}^{2+}$-loaded cation-exchange column followed by elution with ammonium thiosulfate, which although unsuitable for the milk digests, is applicable to aqueous samples.

A new method for the preconcentration of iodide and removal of interferences in the milk digest solutions, via oxidation with $O x o n e \AA$, extraction into toluene and back-extraction into ammonium thiosulfate, has shown some promise, although the extraction efficiency was low. Further measures to control the iodine chemistry during the extraction would need to be developed before this can be considered a viable method for this application.

\section{Acknowledgements}


The authors wish to thank BNFL for advice, sponsorship and provision of samples, and Thermo Analytical for the provision of the PQ ExCell instrument. The laboratory work of former Loughborough University students Geraldine Connally, Matt Dexter, Earny Silva, Claire Tyler, Peter Winship and Shen Xu is also gratefully acknowledged.

\section{References}

[1] R.G. Jensen (ed.), Handbook of Milk Composition, Academic Press, USA, 1995.

[2] F.A.R. Martino, M.L.F. Sanchez and A.S. Medel, J. Anal. At. Spectrom., 15 (2000) 163

[3] P. Bratter, I.N. Blasco, V.E.N. de Bratter and A. Raab, Analyst, 123 (1998) 821.

[4] P.A. Fecher, I. Goldmann and A. Nagengast, J. Anal. At. Spectrom., 13 (1998) 977.

[5] E.H. Larsen, P. Knuthsen and M. Hansen, J. Anal. At. Spectrom., 14 (1999) 41.

[6] L.F. Sanchez and J. Szpunar, J. Anal. At. Spectrom., 14 (1999) 1697.

[7] O.T. Farmer, C.J. Barinaga and D.W. Koppenaal, J. Radioanal. Nucl. Chem., 234 (1998) 153.

[8] B.G. Fritz and G.W. Patton, J. Environ. Radioact., 86 (2006) 64.

[9] K. Simpson, S.J. Parry, and M.J. Fulker, J. Radioanal. Nucl. Chem., 249 (2001) 89.

[10] S.J. Parry, B.A. Bennett, R. Benzing, A.E. Lally, C.P. Birch, and M.J. Fulker, Sci. Total Environ., 173 (1995) 351.

[11] H. Vanhoe, F.V. Allemeersch, J. Versiek, and R. Dams, Analyst, 118 (1993) 1015.

[12] A.V. Izmer, S.F. Bouliger, and J.S. Becker, J. Anal. At. Spectrom., 18 (2003) 1339.

[13] P. Bienvenu, E. Brochard, E. Excoffier, and M. Piccione, Canadian Journal of Analytical Sciences And Spectroscopy, 49 (2004) 423.

[14] H. Baumann, Fresenius' J. Anal.Chem., 338 (1990) 809.

[15] S. Sturup and A. Buchert, Fresenius' J. Anal. Chem., 354 (1996) 323.

[16] R. Hille, Archives of Biochemistry and Biophysics, 433 (2005) 107.

[17] E. Niedobova, J. Machat, V. Otruba and V. Kanicky, J. Anal. At. Spectrom., 20 (2005) 945. 
[18] M. Resano, E. Garcia-Ruiz, L. Moens and V. Vanhaecke, J. Anal. At. Spectrom., 20 (2005) 81.

[19] M.A. Dexter, Ph.D. Thesis, Loughborough University, 2003.

[20] G.C. Eiden, C.J. Barinaga and D.W. Koppenaal, Rapid Commun. Mass Spectrom., 11 (1997) 37.

[21] R. Santamaria-Fernandez, P. Evans, C.S.J. Wolff-Briche and R. Hearn, J. Anal. At. Spectrom., 21 (2006) 413.

[22] M.A. Dexter, H.J. Reid and B.L. Sharp, J. Anal. At. Spectrom., 17 (2002) 676.

[23] A.A. Bashammakh, Ph.D. Thesis, Loughborough University, 2003.

[24] G.K. Koyanagi, D. Caraiman, V. Blagojevic and D.K. Bohme, J. Phys. Chem. A, 106 (2002) 4581.

[25] J.S. Becker, J. Anal. At. Spectrom., 17 (2002) 1172.

[26] DuPont Oxone® Monopersulfate Compound Technical Information, http://www.dupont.com/oxone/techinfo/index.html (accessed 7 Jun 2007)

[27] D.B. Gazda, R.J. Lipert, J.S. Fritz and M.D. Porter, Anal. Chim. Acta, 510 (2004) 241. 